\title{
Research on the Differentiated Impact Mechanism of Parent Company Shareholding and Managerial Ownership on Subsidiary Responsive Innovation: Empirical Analysis Based on 'Principal-Agent' Framework
}

\author{
Peng Xu ${ }^{1}$, Heng Zhang ${ }^{1}$ and Guiyu Bai ${ }^{2, *}$ \\ 1 School of Business Administration, Shandong University of Finance and Economics, Jinan 250014, China; \\ 20157684@sdufe.edu.cn (P.X.); zhanghengedu@mail.sdufe.edu.cn (H.Z.) \\ 2 Business School, University of Jinan, Jinan 250002, China \\ * Correspondence: sm_baigy@ujn.edu.cn
}

Received: 22 August 2019; Accepted: 19 September 2019; Published: 25 September 2019

check for updates

\begin{abstract}
Under the dynamic competition situation, the innovation competition interaction between enterprises will take the form of mutual responding, while the formulation and implementation of responsive innovation strategy will be influenced by both shareholders and managers in the principal-agent relationship. In our research, we try to understand how the difference of governance logic between shareholders and managers affects innovation interaction strategy of enterprises. In order to achieve this research goal, this study takes all eligible listed companies (from 2007 to 2016) in China's stock market as samples. The results show that the parent company shareholding has a negative impact on the subsidiary responsive innovation, while companies whose managers hold more shares select the relatively positive strategy responsive innovation. Moreover, the degree of separation between ownership and control rights and the external institutional environment can moderate the above relationship. Relevant conclusions can provide some reference value for the formulation of responsive innovation decision of listed companies and provide new insights for the design of parent-subsidiary corporate governance structure and the design of managerial equity incentive mechanism in the context of corporate group governance.
\end{abstract}

Keywords: group company; responsive innovation; innovative decision-making; governance logic

\section{Introduction}

Enterprises obtain market position and economic benefits in competition. The consequence of competition affects the future development of enterprises. In many fields involved in enterprise competition, innovation has become the top priority of enterprise competition due to its characteristics of improving productivity and creating competitive advantages [1]. Innovation behavior and innovation competition have also attracted extensive attention of researchers [2,3].

As the two subjects under the principal-agent framework, the major shareholder and the manager have an important influence on the formulation and implementation of corporate strategic decisions. Principal-agent theory holds that the principal and the agent have different objective functions, and the agent will not always act in the best interests of the principal [4]. In other words, there are some differences in the governance logic between the principal and the agent. Moreover, recent research suggests that it is the difference in the governance logic of principal-agent subjects that makes them have different attitudes towards innovation [5]. 
Although the existing literature has made considerable progress in the study of the logical differences of principal-agent governance and enterprise innovation behavior, there are still some problems to be solved as follows: on the one hand, the interactive mechanism of innovation competition among enterprises is still unclear. Most of the existing studies are based on the characteristics of enterprises themselves to analyze the regularity of corporate innovation decision-making $[3,6]$, while dynamic competition theory has noted that the competition among enterprises presents in an interactive form, that is, the innovative competition actions implemented by enterprises in the market will cause the response of competitors. In turn, these innovative responses will affect the choice and implementation of further innovative competition actions of pioneer enterprises [7]. Under the framework of dynamic competition, the choice and formulation of enterprise innovation decision-making is not only limited to its own resources and conditions, but also can be affected by the industry innovation competition situation to a lager extent. On the other hand, the existing research on the governance logic differences between shareholder ownership and managerial ownership is still not clear enough. The shares held by shareholders and managers reflect the distribution ratio of the residual interests of the enterprise. Agency theory holds that endowing managers with residual claim can promote consistent interests of shareholders and managers [8]. According to this idea, the increase in the shareholding ratio of managers and shareholders will make them share the same attitude in making innovative and competitive decisions. However, the conclusion of the existing research is contradictory. Some studies have shown that managerial ownership and shareholder ownership have opposite impacts on corporate innovation $[9,10]$.

In view of the above problems, based on the governance factor of parent company shareholding and managerial ownership ratio, we take listed companies under the framework of Chinese enterprise groups as samples, and investigate the governance logic differences of principal-agent in the process of responsive innovation decision-making. Compared with previous studies, the main contributions of this paper are as follows: Firstly, this paper puts corporate innovation decision-making in the framework of dynamic competition, regarding corporate innovation decision-making with the perspective of industry interaction, thereby eliciting and analyzing corporate responsive innovation-the innovation responding decision-making made by enterprises when facing the innovative competition from competitors. The research on the mechanism of corporate innovation decision-making is more in line with the reality of frequent interactions between businesses. Secondly, this paper explores the difference of governance logic between the principal and the agent when they hold shares at the same time, investigates the changing rule of responsive innovation of listed companies when the shareholding level of the principal and the agent changes, and develops the academic dialogue of the difference of governance logic between the principal and the agent. Third, this paper puts the research on responsive behavior under the special governance situation of enterprise groups, deepening the understanding of the governance effect of enterprise groups. The relevant conclusions can provide some reference value for the formulation of responsive innovation decision-making of listed companies, which are also helpful for the design of parent-subsidiary corporate governance structure and managerial incentive mechanism in the context of corporate group governance.

The remainder of this paper is organized as follows. Section 2 explains the theoretical background and reviews the empirical literature then proposes the hypothesis on the basis of a literature review. Section 3 demonstrates the research design and empirical model, introduces sample selection, data collection, and the definition and measurement of variables. Section 4 describes the empirical results and discussion. Section 5 is the summary of conclusions, contribution to theory, managerial implications, and suggestions for future research. 


\section{Literature Review and Hypothesis Development}

\subsection{Principal Governance Logic: Parent Company Shareholding and Subsidiary Responsive Innovation Decision}

In China's securities market, the controlling methods for listed companies can be divided into two forms: legal person holding and natural person holding. Among them, the existence of legal person holding result in the concept of 'parent holding'. Researchers have made more explorations on the concept of parent company shareholding. For example, Lskavyan and Spatareanu [11] pointed out that the concentration of parent company shareholding may alleviate the negative effects from the weak protection of host country laws for shareholders. Hsieh et al. [12] believe that the difference in the shareholding ratio of the parent company would affect its management way for subsidiaries. Relevant research fully illustrates that the parent company shareholding is a key element in the corporate governance process, which has a tremendous influence on the strategic decision-making of subsidiaries.

Although innovation can create competitive advantages for enterprises, helping enterprises to improve their international competitiveness [13], innovation behavior is also characterized by long investment cycle and output uncertainty [14]. Responsive innovation is an innovative responding decision made by an enterprise facing attack from a competitor that uses innovation as the competitive method. Moderate responsive innovation can create technological advantages for the enterprise and bring about better external evaluation. However, excessive responsive innovation may not only cause the possibility of falling into financial crisis, but also cause greater uncertainty in shaping the competitive advantage of the enterprise due to the increase of legal threats.

Prospect theory holds that when decision makers judge and evaluate a certain scheme under uncertain conditions, they usually set a reference point to judge gains and losses, and make behavioral decisions [15]. The decision reference point is affected by the own subjective value of decision maker. When the decision result is better than the reference point, it would be regarded as gains, otherwise it would be regarded as losses. Decision makers tend to avoid risks when facing gains and to chase risks when facing losses [16]. As the controlling shareholder of the subsidiary company, the main motivation for the parent company to hold the equity of the subsidiary company is to obtain the benefits brought by the subsidiary company in its long-term operation. The increase of the shareholding level of parent companies means that the parent company is optimistic about the prospect of the subsidiary company and believes that the subsidiary company will bring benefits to itself in the future. At this time, the parent company is more inclined to regard the operation of the subsidiary company from a perspective of gains, tending to avoid risks by operating the subsidiary company conservatively, which will reduce responsive innovation. Based on the above analysis, we suggest the following hypothesis:

Hypothesis 1: Parent company shareholding has a negative impact on subsidiary responsive innovation.

Enterprise groups have special governance situations, the separation of ownership and control rights caused by stratification within the group has a profound impact on the strategic behavior of subsidiaries [17,18], which can also significantly influence the value of the enterprise [19]. When the degree of separation between ownership and control rights of the parent company is relatively low in the context of the enterprise group, the risk level formed by the responsive innovation of the subsidiary company will be increased, and the difficulty of risk transfer will also be magnified. The uncertainty of risks will further stimulate the risk aversion tendency of the parent company and urge the parent company to implement more negative responsive innovation. Specifically, as follows:

On the one hand, enterprise groups with relatively high degree of separation between ownership and control have stronger external financing advantages [20]. The existence of resource advantages not only makes enterprise groups more capable of providing financial guarantee for the implementation of responsive innovation, but also diminishes the probability of appearing financial risks if subsidiary responsive innovation is not successful. On the other hand, a high degree of separation of ownership 
and control results in the existence of a complex control chain between the actual controller and the listed company [21], which leads to the possibility for the parent company to disperse risks along the control chain of the listed company. Under the same shareholding level, the higher the degree of separation between ownership and control within the framework of the group, the greater the control right of the actual controller, and the more capable the parent company is to carry out risk transfer. On the contrary, when the degree of separation between ownership and control is relatively low within the framework of the group, it is difficult for the parent company to disperse the risks brought by responsive innovation through the control chain, which may weaken the enthusiasm of the parent company to implement reactive innovation to some extent. Based on the above analysis, we propose the following hypothesis:

Hypothesis 2: The lower the degree of separation between ownership and control rights of the actual controllers, the stronger the negative impact of parent company shareholding on subsidiary responsive innovation.

\subsection{Agent Governance Logic: Subsidiary Managerial Ownership and Responsive Innovation Decisions}

Managerial ownership has always been regarded as an effective method to alleviate the first kind of agency problem. Early studies generally believed that managerial ownership would strengthen the consistency of interests between managers and shareholders. Therefore, in China's listed companies, managerial ownership has gradually become a common incentive method. However, existing research identifies that managerial ownership may also bring about the managerial entrenchment effect [22,23]. When the level of subsidiary managerial ownership rises, the shares managers hold will stimulate their managerial entrenchment mentality, thereby enhancing managers' enthusiasm for corporate responsive innovation. Specifically, as follows:

Managerial entrenchment hypothesis argues that in order to protect their own interests, managers will take defensive actions to maintain their positions and pursue the maximization of their own utility $[24,25]$. The increase of the number of ownership means an increase of the economic benefits involved by the managers in the company. The economic cost that the managers leave the existing position will rise accordingly. The increasing economic cost will urge the managers to industriously seek managerial entrenchment measures. Managerial entrenchment measures include internal entrenchment measures and external entrenchment measures [26]. In the internal entrenchment measures, the main defense object of managers is supervision from the board of directors, which will choose whether to reduce the salary of the managers or dismiss some managers based on evaluation of the managers. The evaluation of managers by the board of directors of the company mainly focuses on the extent of efforts, ability, and the influence of external environment on managers' behavior [26]. Therefore, in order not to be punished by the board of directors, the managers will try their best to ensure that the board of directors regard them as hard-working people or people with high capacity. As the response of listed companies to market competition, the implementation of responsive innovation behavior will highlight the efforts of the managers in the face of market competition. Therefore, in order to obtain a higher evaluation from the board of directors, the management will tend to promote more active responsive innovation.

In addition, the increase of managerial ownership will also enable the managers to gain more control rights and enhance their discourse power in listed companies. The increasing discourse power of the managers can be seen as a social signal, and the reception of this social signal will enhance the self-confidence tendency of the managers [27]. Self-confident managers tend to overestimate investment returns and underestimate investment risks, evaluating the current situation optimistically [28], believing that they can create wealth for shareholders and improve their reputation through investment. The self-confidence of managers makes them show a more positive response attitude when facing the innovative competition methods of other competitors in the market. At this time, managers will promote more responsive innovation behaviors. Based on the above analysis, we propose the following hypothesis: 
Hypothesis 3: Subsidiary managerial ownership has a positive impact on subsidiary responsive innovation.

Leadership structure allocation refers to the listed company's selection of the position allocation status of chairman and CEO, including two situations of concurrence and separation of two positions. The choice of leadership allocation reflects the independence of the board of directors and the autonomy of the executive [29], which is an important internal governance mechanism for modern companies to coordinate the relationship between the board of directors and the executive. Referring to existing research, the relatively centralized leadership structure of subsidiaries will affect the relationship between managerial ownership and responsive innovation through the following paths:

The leadership structure of the separation between CEO and chairman of directors makes the power distribution within the company more balanced, increasing the board's restraint and supervision on the managers of listed companies [30]. On the contrary, leadership structure of CEO duality has a positive influence on reducing the internal communication time of the enterprise and reducing the divergence between the board and the executives, which can effectively diminish the conflicts between the board and the executives [31]. When the listed companies are in the leadership structure situation of CEO duality, it is easier for the manager to break through the defense of the board of directors, which is the "first line of defense" of internal governance [32], and the approval and implementation of the management decisions of the listed companies will be smoother. The smooth decision-making will enable the managers obtain the social signal that they forcefully dominate the listed companies in the daily operation activities, thus stimulating the self-confidence of managers and eventually promote the listed companies to carry out higher-level responsive innovation. Based on the above analysis, we propose the following hypothesis:

Hypothesis 4: The relatively centralized leadership structure of subsidiaries will strengthen the positive impact of managerial ownership on responsive innovation.

The overall study model is shown in Figure 1.

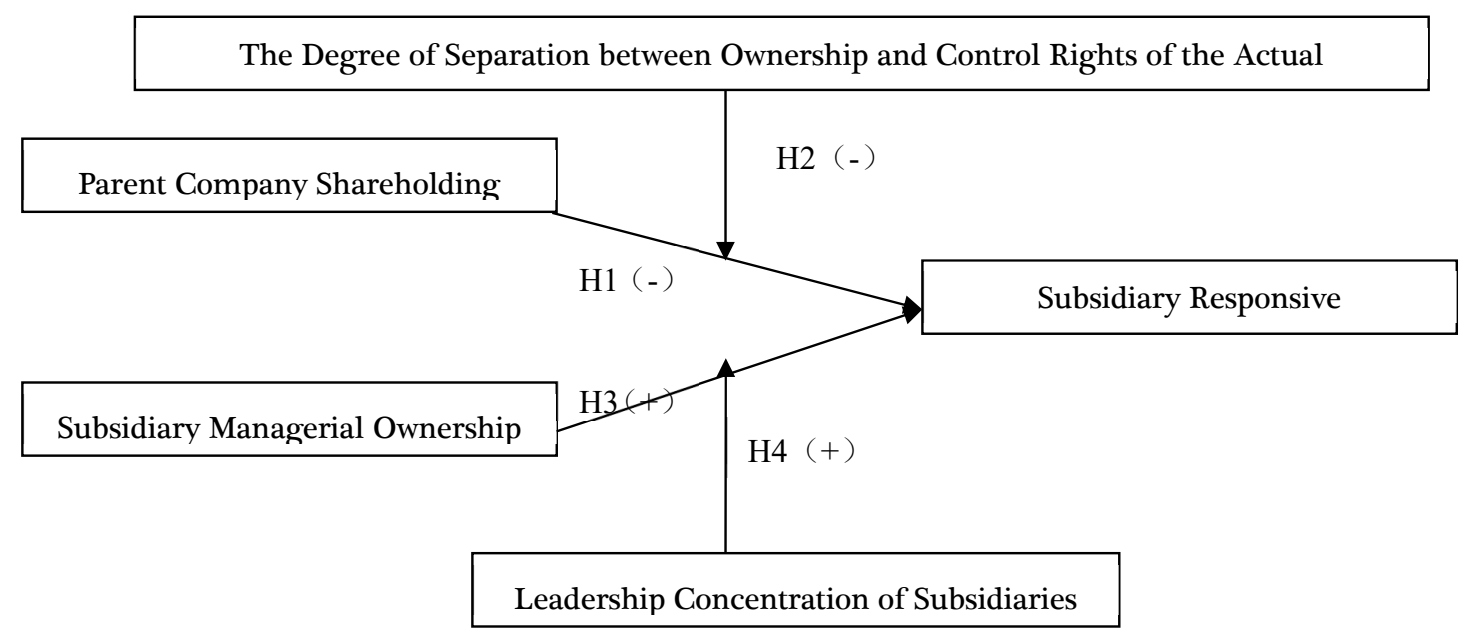

Figure 1. Hypothesized model.

\section{Research Design}

\subsection{Sample Selection and Data Collection}

This paper selects listed companies of enterprise groups in Shanghai and Shenzhen stock markets as the research object. There are several reasons for this: First of all, listed companies of enterprise groups account for the majority of listed companies in Shanghai and Shenzhen stock markets in China, so they are representative to a certain extent; Second, in the same listed company, natural person 
shareholders have complicated connections, and there is a common phenomenon that multiple natural person shareholders constitute interest groups. At this time, it is difficult to count the major shareholders' shareholdings. Third, there may be some differences between the natural person shareholding and the parent company shareholding. Selecting listed companies of enterprise groups as research objects is conducive to controlling such differences.

Referring to the division of the company of enterprise groups in existing literature [30], this paper takes all listed companies (from 2007 to 2016) in Shanghai and Shenzhen stock markets as the basic samples, and excludes the following samples:

(1) Financial industry companies

(2) Special treatment and delisted companies

(3) Samples with missing data

(4) Companies whose direct controller is not a corporation

This paper selects 2007-2016 as the observation period of the sample. There are several reasons for this: First of all, the measurement data of responsive innovation of listed companies are taken from the 'research and development costs' of listed companies. The 'New Accounting Standards', implemented since 2007, require enterprises to disclose research and development information, laying a foundation for the availability of key data. On the other hand, it is because Article 33 of the 2007 revised guidelines on the content and format of corporate information disclosure for publicly issued securities No. 2 by the CSRC requires that "companies should remind investors of future corporate development opportunities and challenges, business plans and research and development plans for the new year should be disclosed". Under this background, more and more listed companies have disclosed research and development plans. Third, the paper takes into account the availability of data and the requirement of sample sizes for large sample studies.

The basic data reflecting the responsive innovation of listed companies in this study are selected from the annual research and development expenses of enterprises disclosed in Wind database, and the data of parent company shareholding, subsidiary company managerial ownership and control variables are all selected from CSMAR database (CSMAR database is an economic and financial database developed from the needs of academic research).

\subsection{Variable Definition and Measurement}

\subsubsection{Dependent Variable}

Subsidiary responsive innovation (SRI). Dynamic competition theory emphasizes the interaction between competitors in the same industry, whose core idea is that some enterprises will initiate certain competitive actions to promote or maintain their competitive position, while other enterprises in the industry will fight back against this competitive action [33]. As a concept formed based on dynamic competition theory, the measurement of responsive innovation should reflect the responsive tendency of listed companies to the innovation competition situation in the industry. Based on this, we designed the following formula:

$$
S R I_{j, t}=T I_{j, t} / \frac{\sum_{j=1}^{n} T I_{j, t-1}}{n}
$$

In the formula, $T I j, t$ represents the technological innovation investment of listed company $j$ in a certain industry in $\mathrm{t}$ year, $\sum_{j=1}^{n} T I_{j, t-1} / n$ represents the average level of technological innovation investment in the industry to which the company $\mathrm{j}$ belongs in $\mathrm{t}-1$ year. The ratio of the two reflects the responsive innovation behavior (i.e., $S R I j, t$ ) implemented by the listed company $\mathrm{j}$ in $\mathrm{t}$ year based on the average level of technological innovation in the industry in $\mathrm{t}-1$ year. The larger the value of $S R I j, t$, the more positive the responsive innovation in the dynamic competition in that year. 


\subsubsection{Independent Variables}

Parent company shareholding (PCS) is the proportion of the parent company shareholding in the total equity of the listed company. Subsidiary managerial ownership (SMO) is measured by the ratio of managerial ownership of listed companies to the total equity of listed companies. According to the existing research [34,35], the article measures the parent company shareholding with the proportion of the parent company shareholding in the total equity of the listed company, and measures the subsidiary managerial ownership with the ratio of the executive's ownership of listed companies to the total equity of listed companies. With the improvement of their shareholding level, the degree of their embedding in the listed companies is constantly increasing. At this time, the interests of both are more closely linked with the listed companies. Under the condition that the difference between shareholders and managers is narrowed, the article hopes to further clarify the difference of governance logic between shareholders and managers by comparing their attitudes towards responsive innovation strategies, which may be helpful for developing the agency theory.

\subsubsection{Moderating Variable}

The degree of separation between ownership and control right (SOC) is the moderating variable. In this paper, the deviation degree between ownership and control of the actual controller is taken as a moderating variable. Referring to the measurement method in the existing literature [36,37], the variable is measured by the difference between control right and ownership. Specifically, control right is measured by the sum of the minimum shareholding ratio in each control chain, and ownership is measured by the sum of the product of shareholding proportions of each link in each control chain.

Subsidiary leadership structure (SLS). In this paper, the leadership structure of a subsidiary is taken as the second moderator variable. To measure the variable of subsidiary leadership structure, the article refers to the existing research [38] that study the power structure of companies, whose result is that the power structure of CEO duality will affect the board's involvement in strategic decision making. Thus, we construct the dummy variable SLS, defined as 1 for CEO duality, and 0 otherwise. The leadership structure of CEO duality endows listed company with a more centralized leadership structure, whereas the leadership structure of the separation between CEO and chairman of directors makes the power distribution within the company more balanced. Therefore, we believe that when this variable is set to 1 , the decision-making process of $\mathrm{CEO}$ and other executives will be smoother.

\subsubsection{Control Variable}

In addition, this paper also selects the factors that may affect the innovation behavior of listed companies-such as the nature of the parent company shareholding (PC), the independence of subsidiary board of directors (ISB), the size of subsidiary board of directors (SSB), the asset-liability ratio of the subsidiary (ALRS), and the size of the subsidiary (SS) - as the control variables of this study. The existing literature on control variables is summarized as shown in Table 1. Hall and Ziedonis (2011) argue that the number of patent applications is positively related to firm size [44]. Therefore, referring to existing literature [47], we control the variable of firm size, measured by the natural logarithm of total asset. We control the firm leverage, measured by the ratio of total liabilities to total assets of listed companies at the end of the year [41]. The nature of the parent company shareholding is also controlled, measured by a dummy variable [40]. Finally, the independence of subsidiary board of directors and the size of subsidiary board of directors are controlled, measured by the proportion of independent directors in the board of directors [48] and the number of the board of directors [45]. The specific definitions and measurement methods of each variable are shown in Table 2. 
Table 1. Source of control variables

\begin{tabular}{|c|c|c|c|}
\hline Research Level & Variables & Research Results & Author \\
\hline Nature of equity & $\begin{array}{l}\text { Nature of the parent company } \\
\text { shareholding (PC) }\end{array}$ & $\begin{array}{c}\text { The existence of state-owned shares is conducive to } \\
\text { innovation. }\end{array}$ & $\begin{array}{l}\text { Choi et al. (2011) [39] } \\
\text { Zhou et al. (2017) [40] }\end{array}$ \\
\hline Company characteristics & $\begin{array}{l}\text { Asset-liability ratio of subsidiaries } \\
\text { (ALRS) }\end{array}$ & $\begin{array}{l}\text { The capital structure of an enterprise will affect } \\
\text { innovation, moderated by enterprise scale and } \\
\text { economic environment. }\end{array}$ & $\begin{array}{l}\text { Bartoloni (2013) [41] } \\
\text { Li \& Simerly (2002) [42] }\end{array}$ \\
\hline \multirow{3}{*}{ Board characteristics } & Size of subsidiaries (SS) & $\begin{array}{l}\text { The number of patent applications is positively } \\
\text { related to firm size }\end{array}$ & $\begin{array}{l}\text { Shefer \& Frenkel (2005) [43] } \\
\text { Hall \& Ziedonis(2001) [44] }\end{array}$ \\
\hline & $\begin{array}{l}\text { Size of the subsidiary board of } \\
\text { directors (SSB) }\end{array}$ & $\begin{array}{c}\text { Too many or too few board members are not } \\
\text { conducive to innovation. }\end{array}$ & Zahra et al. (2000) [45] \\
\hline & $\begin{array}{l}\text { Independence of subsidiary board } \\
\text { of directors (ISB) }\end{array}$ & $\begin{array}{c}\text { Independent boards of directors are more effective in } \\
\text { improving innovation. }\end{array}$ & Balsmeier et al. (2017) [46] \\
\hline
\end{tabular}

Table 2. Definition and measurement of variables

\begin{tabular}{|c|c|c|}
\hline Variables & Code & Index \\
\hline Subsidiary responsive innovation (SRI) & SRI & A calculation formula is designed based on dynamic competition theory \\
\hline Parent company shareholding & PCS & The proportion of parent company shareholding to total equity of listed companies \\
\hline Subsidiary managerial ownership & $\mathrm{SMO}$ & The proportion of managerial ownership in total equity of listed companies \\
\hline Leadership structure of subsidiaries & SLS & CEO duality is ' 1 ', otherwise ' 0 '. \\
\hline Nature of the parent company shareholding & PC & State-owned is ' 1 ' and non-state-owned is ' 0 '. \\
\hline Size of the subsidiary board of directors & SSB & Number of the Board of Directors of Listed Companies \\
\hline Independence of subsidiary board of directors & ISB & $\begin{array}{l}\text { The proportion of independent directors in the board of directors of listed companies } \\
\text { at the end of the year }\end{array}$ \\
\hline Asset-liability ratio of subsidiaries & ALRS & The ratio of total liabilities to total assets of listed companies at the end of the year \\
\hline Size of subsidiaries & SS & The logarithm of total assets of listed companies at the end of the year \\
\hline
\end{tabular}




\subsection{Models}

In order to verify the research hypothesis proposed in this paper, the following multiple regression models are designed:

$$
\begin{gathered}
\text { Model 1: SRI }=c+\sum_{j=1}^{n} b_{j} \text { Control }+\varepsilon \\
\text { Model 2: SRI }=c+\sum_{j=1}^{n} b_{j} \text { Control }+a P C S+\varepsilon \\
\text { Model 3: SRI }=c+\sum_{j=1}^{n} b_{j} \text { Control }+a_{1} P C S+a_{2} P C S * S O C+\varepsilon \\
\text { Model 4: SRI }=c+\sum_{j=1}^{n} b_{j} \text { Control }+a S M O+\varepsilon \\
\text { Model 5: SRI }=c+\sum_{j=1}^{n} b_{j} \text { Control }+a_{1} S M O+a_{2} S M O * S L S+\varepsilon
\end{gathered}
$$

Among them, Control is the control variable group, $c$ is the intercept term, $\varepsilon$ represents the random disturbance term, $j$ is the number for each control variable, $b_{j}$ represents the regression coefficient of each control variable, and $a$ represents the regression coefficient of each independent variable. Model 1 is a regression model of the control variables and the dependent variable. Model 2 adds an independent variable to Model 1 to test the correlation between parent company shareholding and responsive innovation, that is, hypothesis $\mathrm{H} 1$. Based on model 2, model 3 adds an interaction term to test the moderating effect of the degree of separation between ownership and control, i.e., hypothesis H2. Model 4 adds another independent variable to model 1 to test the correlation between managerial ownership and responsive innovation, i.e., hypothesis H3. Based on model 4, model 5 adds another interaction term to test the moderating effect of leadership structure, i.e., hypothesis $\mathrm{H} 4$.

It should be noted that since some variables (such as the nature of the parent company shareholding) included in the article do not change with time, the article does not use the fixed effect model, but uses OLS regression method to analyze the data of the article.

\section{Empirical Results}

\subsection{Descriptive Statistics}

Table 3 shows the data characteristics of several main variables from 2007 to 2016 . It can be found that the average value of responsive innovation over the years is nearly twice the median, which indicates that there is a big gap in the innovation responding of different enterprises. The median of parent company shareholding is apparently higher than the median of subsidiary managerial ownership, which indicates that although the phenomenon of managerial ownership is common in contemporary companies, the number of shares managers held is still far lower than major shareholders. It could be believed that this absolute difference in quantity leads to the difference in quality and the difference in governance logic between managers and major shareholders.

From a vertical point of view, except the variable of parent company shareholding which generally show a downward trend, the mean and median of other variables fluctuate in a certain range, and there is no obvious upward and downward trend. The mean of responsive innovation varies in different years, and the change direction of the median of the variable is basically consistent with the average value, which indicates that the innovation interaction strategy of most enterprises in the same industry will be influenced by other enterprises, showing a feature of changing in sync. 
Table 3. Descriptive statistics of variables.

\begin{tabular}{|c|c|c|c|c|c|c|c|}
\hline Year & Variable & $\mathbf{N}$ & Mean & Median & SD & Min & Max \\
\hline \multirow{5}{*}{2007} & SRI & 82 & 1.812 & 0.805 & 2.833 & 0.010 & 15.500 \\
\hline & PCS & 82 & 0.404 & 0.395 & 0.141 & 0.140 & 0.760 \\
\hline & SMO & 82 & 0.004 & 0.000 & 0.022 & 0.000 & 0.180 \\
\hline & SOC & 82 & 1.442 & 1.000 & 1.004 & 1.000 & 8.280 \\
\hline & SLS & 82 & 0.085 & 0.000 & 0.281 & 0.000 & 1.000 \\
\hline \multirow{5}{*}{2008} & SRI & 111 & 1.262 & 0.670 & 1.780 & 0.010 & 10.140 \\
\hline & PCS & 111 & 0.401 & 0.396 & 0.139 & 0.130 & 0.760 \\
\hline & SMO & 111 & 0.008 & 0.000 & 0.035 & 0.000 & 0.230 \\
\hline & SOC & 111 & 1.789 & 1.000 & 3.602 & 1.000 & 38.480 \\
\hline & SLS & 111 & 0.081 & 0.000 & 0.274 & 0.000 & 1.000 \\
\hline \multirow{5}{*}{2009} & SRI & 106 & 1.508 & 0.728 & 2.180 & 0.000 & 11.620 \\
\hline & PCS & 106 & 0.397 & 0.393 & 0.131 & 0.120 & 0.790 \\
\hline & $\mathrm{SMO}$ & 106 & 0.010 & 0.000 & 0.036 & 0.000 & 0.250 \\
\hline & SOC & 106 & 1.459 & 1.073 & 0.743 & 1.000 & 6.010 \\
\hline & SLS & 106 & 0.085 & 0.000 & 0.280 & 0.000 & 1.000 \\
\hline \multirow{5}{*}{2010} & SRI & 161 & 2.041 & 0.930 & 3.418 & 0.000 & 30.070 \\
\hline & PCS & 161 & 0.386 & 0.370 & 0.137 & 0.110 & 0.760 \\
\hline & $\mathrm{SMO}$ & 161 & 0.007 & 0.000 & 0.028 & 0.000 & 0.210 \\
\hline & SOC & 161 & 1.519 & 1.104 & 0.846 & 1.000 & 6.010 \\
\hline & SLS & 161 & 0.106 & 0.000 & 0.308 & 0.000 & 1.000 \\
\hline \multirow{5}{*}{2011} & SRI & 270 & 1.586 & 0.804 & 3.048 & 0.000 & 32.800 \\
\hline & PCS & 270 & 0.379 & 0.361 & 0.145 & 0.070 & 0.850 \\
\hline & SMO & 270 & 0.006 & 0.000 & 0.027 & 0.000 & 0.240 \\
\hline & SOC & 270 & 1.484 & 1.108 & 0.768 & 1.000 & 6.230 \\
\hline & SLS & 270 & 0.122 & 0.000 & 0.328 & 0.000 & 1.000 \\
\hline \multirow{5}{*}{2012} & SRI & 302 & 2.720 & 1.282 & 4.691 & 0.000 & 39.520 \\
\hline & CEP & 302 & 0.380 & 0.363 & 0.147 & 0.070 & 0.850 \\
\hline & SMO & 302 & 0.006 & 0.000 & 0.025 & 0.000 & 0.240 \\
\hline & SOC & 302 & 1.486 & 1.088 & 0.814 & 1.000 & 6.360 \\
\hline & SLS & 302 & 0.126 & 0.000 & 0.332 & 0.000 & 1.000 \\
\hline \multirow{5}{*}{2013} & SRI & 381 & 1.806 & 0.875 & 2.820 & 0.000 & 19.330 \\
\hline & PCS & 381 & 0.373 & 0.361 & 0.148 & 0.000 & 0.820 \\
\hline & SMO & 381 & 0.005 & 0.000 & 0.022 & 0.000 & 0.230 \\
\hline & SOC & 381 & 1.488 & 1.071 & 0.801 & 1.000 & 6.530 \\
\hline & SLS & 381 & 0.121 & 0.000 & 0.326 & 0.000 & 1.000 \\
\hline \multirow{5}{*}{2014} & SRI & 396 & 1.642 & 0.835 & 2.491 & 0.000 & 21.480 \\
\hline & PCS & 396 & 0.371 & 0.355 & 0.147 & 0.070 & 0.820 \\
\hline & SMO & 396 & 0.005 & 0.000 & 0.021 & 0.000 & 0.230 \\
\hline & SOC & 396 & 1.493 & 1.052 & 0.917 & 1.000 & 9.360 \\
\hline & SLS & 396 & 0.134 & 0.000 & 0.341 & 0.000 & 1.000 \\
\hline \multirow{5}{*}{2015} & SRI & 411 & 1.607 & 0.811 & 2.369 & 0.000 & 20.740 \\
\hline & PCS & 411 & 0.364 & 0.343 & 0.143 & 0.070 & 0.800 \\
\hline & SMO & 411 & 0.007 & 0.000 & 0.036 & 0.000 & 0.430 \\
\hline & SOC & 411 & 1.433 & 1.046 & 0.776 & 1.000 & 6.650 \\
\hline & SLS & 411 & 0.114 & 0.000 & 0.319 & 0.000 & 1.000 \\
\hline \multirow{5}{*}{2016} & SRI & 424 & 1.521 & 0.817 & 2.256 & 0.000 & 21.060 \\
\hline & PCS & 424 & 0.356 & 0.341 & 0.140 & 0.070 & 0.780 \\
\hline & SMO & 424 & 0.009 & 0.000 & 0.041 & 0.000 & 0.430 \\
\hline & SOC & 424 & 1.426 & 1.044 & 0.746 & 1.000 & 6.730 \\
\hline & SLS & 424 & 0.120 & 0.000 & 0.326 & 0.000 & 1.000 \\
\hline
\end{tabular}




\subsection{Multiple Regression Analysis}

Based on the model designed above, the article uses statistical software to carry out regression analysis. The specific regression results are shown in Table 4 . The regression results of model 1 show that there is a significant relationship between responsive innovation behavior and the nature of the parent company shareholding and the size of subsidiaries, which supports the existing research $[39,40,43,44]$. The above results also confirm one of the core ideas of the article: Taking risks is one of the conditions required for innovation, the state-owned nature and larger scale of enterprises enable enterprises to face the risks associated with innovation without fear of risks.

Table 4. Regression results

\begin{tabular}{|c|c|c|c|c|c|}
\hline \multirow{2}{*}{ Variable } & \multicolumn{5}{|c|}{ Responsive Innovation } \\
\hline & M1 & M2 & M3 & M4 & M5 \\
\hline Constant Term & $\begin{array}{l}-0.019 \\
(-0.83)\end{array}$ & $\begin{array}{l}-0.025 \\
(-1.06)\end{array}$ & $\begin{array}{l}-0.021 \\
(-0.89)\end{array}$ & $\begin{array}{l}-0.024 \\
(-1.04)\end{array}$ & $\begin{array}{l}-0.024 \\
(-1.05)\end{array}$ \\
\hline \multicolumn{6}{|l|}{ Control Variable } \\
\hline PC & $\begin{array}{l}0.079 \text { * } \\
(1.76)\end{array}$ & $\begin{array}{l}0.087 \text { * } \\
(1.92)\end{array}$ & $\begin{array}{l}0.084 \text { * } \\
(1.85)\end{array}$ & $\begin{array}{c}0.090 \text { ** } \\
(1.98)\end{array}$ & $\begin{array}{c}0.090 \text { ** } \\
(1.99)\end{array}$ \\
\hline SSB & $\begin{array}{l}-0.028 \\
(-1.31)\end{array}$ & $\begin{array}{l}-0.026 \\
(-1.23)\end{array}$ & $\begin{array}{l}-0.025 \\
(-1.19)\end{array}$ & $\begin{array}{l}-0.027 \\
(-1.28)\end{array}$ & $\begin{array}{l}-0.027 \\
(-1.28)\end{array}$ \\
\hline ISB & $\begin{array}{l}0.001 \\
(0.03)\end{array}$ & $\begin{array}{l}-0.002 \\
(-0.12)\end{array}$ & $\begin{array}{l}-0.002 \\
(-0.11)\end{array}$ & $\begin{array}{l}0.008 \\
(0.39)\end{array}$ & $\begin{array}{l}0.007 \\
(0.37)\end{array}$ \\
\hline ALRS & $\begin{array}{c}-0.115^{* * *} \\
(-5.40)\end{array}$ & $\begin{array}{c}-0.118^{* * *} \\
(-5.52)\end{array}$ & $\begin{array}{c}-0.118^{* * *} \\
(-5.51)\end{array}$ & $\begin{array}{c}-0.110^{* * *} \\
(-5.14)\end{array}$ & $\begin{array}{c}-0.110 * * * \\
(-5.15)\end{array}$ \\
\hline SS & $\begin{array}{c}0.435^{* * *} \\
(19.48)\end{array}$ & $\begin{array}{c}0.442 * * * \\
(18.99)\end{array}$ & $\begin{array}{c}0.446^{* * *} \\
(19.07)\end{array}$ & $\begin{array}{c}0.439 * * * \\
(19.57)\end{array}$ & $\begin{array}{c}0.439 * * * \\
(19.58)\end{array}$ \\
\hline \multicolumn{6}{|l|}{ Moderator Variable } \\
\hline SOC & $\begin{array}{c}0.071^{* * *} \\
(3.57)\end{array}$ & $\begin{array}{c}0.068^{* * *} \\
(3.37)\end{array}$ & $\begin{array}{c}0.081^{* * *} \\
(3.74)\end{array}$ & $\begin{array}{c}0.071^{* * *} \\
(3.55)\end{array}$ & $\begin{array}{c}0.071^{* * *} \\
(3.55)\end{array}$ \\
\hline SLS & $\begin{array}{l}0.091 \\
(1.54)\end{array}$ & $\begin{array}{c}0.108 * \\
(1.79)\end{array}$ & $\begin{array}{c}0.110 * \\
(1.83)\end{array}$ & $\begin{array}{c}0.100 * \\
(1.67)\end{array}$ & $\begin{array}{c}0.099 * \\
(1.65)\end{array}$ \\
\hline \multicolumn{6}{|l|}{$\begin{array}{l}\text { Independent } \\
\text { Variable }\end{array}$} \\
\hline PCS & & $\begin{array}{c}-0.054^{* * *} \\
(-2.63)\end{array}$ & $\begin{array}{c}-0.051^{* *} \\
(-2.48)\end{array}$ & & \\
\hline $\mathrm{SMO}$ & & & & $\begin{array}{c}0.046^{* *} \\
(2.37)\end{array}$ & $\begin{array}{c}0.043 \text { ** } \\
(2.13)\end{array}$ \\
\hline \multicolumn{6}{|l|}{ Interactive Term } \\
\hline PCS*SOC & & & $\begin{array}{l}0.038^{*} \\
(1.65)\end{array}$ & & \\
\hline SMO*SLS & & & & & $\begin{array}{l}0.042 \\
(0.58)\end{array}$ \\
\hline $\mathrm{R}^{2}$ & 0.1481 & 0.1457 & 0.1467 & 0.1520 & 0.1521 \\
\hline $\mathrm{F}$ & 59.31 & 49.90 & 44.70 & 52.98 & 47.12 \\
\hline $\mathrm{N}$ & 2396 & 2350 & 2350 & 2374 & 2374 \\
\hline
\end{tabular}

Note: ${ }^{* * *},{ }^{* *},{ }^{*}$ represents $p<0.01, p<0.05, p<0.1$ respectively.

After controlling the relevant variables, model 2 adds the parent company shareholding as an explanatory variable. The results show that there is a significant correlation between the parent company shareholding and responsive innovation $(p<0.01)$, with a regression coefficient of -0.054 and a goodness of fit of 0.148 . The regression results of model 2 show that the parent company shareholding has a negative impact on responsive innovation, the higher the parent company shareholding, the lower the subsidiary responsive innovation level, Hypothesis 1 is thus verified. Innovation has high potential benefits and considerable risks [13,14]. Enterprise groups have the characteristic of sharing risks; bring great innovation advantages to group companies. However, as the degree of connection between the parent company and the subsidiary company increases, the interest binding between the parent 
company and the subsidiary company further deepens, and the parent company can only disperse fewer risks, so it does not want the subsidiary company to take more risks.

The regression results of model 3 point out that under the condition of controlling variables such as the asset-liability ratio of subsidiaries and the size of subsidiaries, there is a significant positive correlation $(p<0.1)$ between responsive innovation and the interaction term, with a coefficient of 0.038 and a goodness of fit of 0.147 . This shows that, within the framework of the corporate group, the lower the degree of separation between ownership and control, the stronger the negative impact of the parent company shareholding on the subsidiary responsive innovation, Hypothesis 2 is thus verified. The higher degree of separation between control rights and cash flow rights leads to a complicated control chain between the actual controller and the listed company [21]. At this time, the parent company can take fewer risks under the same control rights, which also gives the parent company stronger motivation to support the innovation of subsidiaries.

After controlling the relevant variables, model 4 adds subsidiary managerial ownership as an explanatory variable. The results show that there is a significant correlation between subsidiary managerial ownership and responsive innovation $(p<0.05)$, with a regression coefficient of 0.046 and a goodness of fit of 0.152 . The regression results of model 4 show that subsidiary managerial ownership has a positive impact on responsive innovation. With the increase of subsidiary managerial ownership, the level of subsidiary responsive innovation will also increase, Hypothesis 3 is thus verified. With the improvement of the level of managerial ownership, innovation becomes profitable. Successful innovation can enhance the value of the enterprise, thus benefiting the management who holds shares. Even if the innovation fails, the process of innovation can be a foil for the efforts of managers. Therefore, with the increase of shareholding level, managers are also more inclined to promote innovation in a company.

The regression results of model 5 show that under the condition of controlling variables such as subsidiary asset-liability ratio and subsidiary size, there is no significant correlation between the interaction term and responsive innovation, Hypothesis 4 has not been verified. The hypotheses proposed in this paper have been verified partially, see Table 5 for details.

Table 5. Hypotheses and whether hypotheses are verified

\begin{tabular}{ccc}
\hline & \multicolumn{1}{c}{ Hypotheses } & Whether Hypotheses are Verified \\
\hline Hypothesis 1 & $\begin{array}{c}\text { Parent company shareholding has a negative } \\
\text { impact on subsidiary responsive innovation. } \\
\text { The lower the degree of separation between } \\
\text { ownership and control rights of the actual } \\
\text { controllers, the stronger the negative impact of } \\
\text { parent company shareholding on subsidiary } \\
\text { responsive innovation. }\end{array}$ & YES \\
Hypothesis 3 & $\begin{array}{l}\text { Subsidiary managerial ownership has a positive } \\
\text { impact on subsidiary responsive innovation. } \\
\text { The relatively centralized leadership structure of } \\
\text { Subsidiaries will strengthen the positive impact of } \\
\text { managerial ownership on responsive innovation. }\end{array}$ & YES \\
\end{tabular}

\subsection{Further Analysis}

The external institutional environment (IE) reflects the living conditions of enterprises, vitally influencing the development of enterprises. The previous section mainly considered the moderating effect of internal governance factors such as the separation of ownership and control and leadership structure on listed companies' responsive innovation behavior, but the discussion about moderating effect of the institutional environment factor may be limited. In order to make the research more comprehensive, this paper further analyzes the effect of institutional environment, an external factor, on responsive innovation behavior. It is hoped that through statistical analysis of the relationship 
between responsive innovation behavior and institutional environment, the role of institutional environment in responsive innovation decision-making of listed companies will be investigated.

The measurement of the institutional environment refers to the evaluation of the overall progress of the market-oriented reform in China's provinces in China Sub-Province Market Index Report (2016), which includes factors such as the relationship between the government and the market, the development of non-state-owned economy, the developing level of product market, the developing level of factor market, the development of market intermediary organizations and the legal institutional environment, and can relatively reasonably reflect the institutional environment currently faced by China's listed companies.

On the basis of the previous content, this paper maintains the original explanatory variables and control variables and takes the institutional environment as a moderator variable to be included in the analysis. The specific operation is to add the interaction term between the parent company shareholding and the institutional environment on the basis of model M2, and add the interaction term between managerial ownership and institutional environment on the basis of model M4.

M6 in Table 6 shows that there is a significant positive correlation between the interaction term and responsive innovation $(p<0.05)$, with a coefficient of 0.050 and a goodness of fit of the model of 0.154. It means that the improvement of external institutional environment will weaken the negative impact of parent company shareholding on subsidiary responsive innovation. The reason may be that the improvement of external institutional environment reduces the legitimacy challenge of innovation, augmenting the probability of success of responsive innovation behavior, decreasing the risk of the parent company, eventually inducing more responsive innovation behavior.

Table 6. Further analysis

\begin{tabular}{|c|c|c|}
\hline \multirow{2}{*}{ Variable } & \multicolumn{2}{|c|}{ Responsive Innovation } \\
\hline & M6 & M7 \\
\hline Constant Term & $\begin{array}{l}-0.022 \\
(-0.92)\end{array}$ & $\begin{array}{l}-0.004 \\
(-0.16)\end{array}$ \\
\hline \multicolumn{3}{|l|}{ Control Variable } \\
\hline PC & $\begin{array}{l}0.106^{* *} \\
(2.31)\end{array}$ & $\begin{array}{l}0.102 \text { ** } \\
(2.24)\end{array}$ \\
\hline SSB & $\begin{array}{l}-0.024 \\
(-1.13)\end{array}$ & $\begin{array}{l}-0.024 \\
(-1.11)\end{array}$ \\
\hline ISB & $\begin{array}{l}-0.003 \\
(-0.15)\end{array}$ & $\begin{array}{l}0.008 \\
(0.42)\end{array}$ \\
\hline ALRS & $\begin{array}{c}-0.100^{* * *} \\
(-4.63)\end{array}$ & $\begin{array}{c}-0.095^{* * *} \\
(-4.37)\end{array}$ \\
\hline SS & $\begin{array}{c}0.437^{* * *} \\
(18.52)\end{array}$ & $\begin{array}{c}0.434^{* * * *} \\
(19.20)\end{array}$ \\
\hline \multicolumn{3}{|l|}{ Moderator Variable } \\
\hline $\mathrm{SOC}$ & $\begin{array}{c}0.070 * * * \\
(3.42)\end{array}$ & $\begin{array}{c}0.070 * * * \\
(3.48)\end{array}$ \\
\hline SLS & $\begin{array}{l}0.082 \\
(1.36)\end{array}$ & $\begin{array}{l}0.077 \\
(1.29)\end{array}$ \\
\hline Institutional Environment (IE) & $\begin{array}{c}0.080^{* * *} \\
(4.07)\end{array}$ & $\begin{array}{c}0.059^{* * *} \\
(2.92)\end{array}$ \\
\hline \multicolumn{3}{|l|}{ Independent Variable } \\
\hline PCS & $\begin{array}{c}-0.041 \text { ** } \\
(-1.98)\end{array}$ & \\
\hline SMO & & $\begin{array}{c}0.121^{* * *} \\
(3.60)\end{array}$ \\
\hline \multicolumn{3}{|l|}{ Interactive Term } \\
\hline PCS*IE & $\begin{array}{l}0.050 \text { ** } \\
(2.51)\end{array}$ & \\
\hline SMO*IE & & $\begin{array}{c}-0.102 * * * \\
(-3.16)\end{array}$ \\
\hline $\mathbf{R}^{2}$ & 0.154 & 0.161 \\
\hline $\mathbf{F}$ & 42.20 & 44.91 \\
\hline $\mathbf{N}$ & 2327 & 2349 \\
\hline
\end{tabular}

Note: ${ }^{* * *}, * *$ represents $p<0.01, p<0.05$ respectively. The value of $\mathrm{t}$ is in parentheses. 
M7 in Table 6 reports that there is a significant positive correlation between the interaction term and responsive innovation $(p<0.01)$, with a coefficient of -0.102 and a goodness of fit of 0.161. It shows that a high-level external institutional environment will weaken the positive impact of managerial ownership on subsidiary responsive innovation. The improvement of the external institutional environment can reduce the legal challenge of innovation, decreasing the risks borne by the parent company, enabling the parent company to carry out more innovation. However, at the same time, with the increase of the institutional environment, more companies participate in the innovation interaction. The generalization of innovation interaction makes it difficult for innovation behavior to reflect the efforts of managers, and the enthusiasm of managers to promote responsive innovation behavior also decreases.

\section{Conclusions and Enlightenment}

\subsection{Research Conclusions}

This paper deduces the decision logic of response innovation of listed companies in enterprise groups through prospect theory and principal-agent theory, and makes a statistical analysis of the relevant decision logic and effect by using the data of listed companies in enterprise groups in China. The results show that: First, the parent company shareholding has a negative impact on the subsidiary responsive innovation. Second, a lower degree of separation between ownership and control enhances the functioning of parent company shareholding in reducing subsidiary responsive innovation. Third, companies whose managers hold fewer shares select the relatively negative strategy responsive innovation. Further research finds that the improvement of external institutional environment will weaken the negative effect of parent company shareholding and the positive effect of managerial ownership.

It should be noted that the moderating effect of $\mathrm{CEO}$ duality on the relationship between managerial ownership and responsive innovation has not been verified. A possible explanation is that CEO duality makes the manager position in the company more deeply rooted [49], which makes it difficult for the board of directors to carry out effective supervision. The managerial entrenchment motivation is correspondingly weakened, and there it is not necessary to highlight their own efforts by actively responding to competitors' innovative competition.

\subsection{Contribution to Theory}

In recent years, researchers have continuously deepened their research on corporate innovation, exploring various dimensions and classifications of innovation such as breakthrough innovation and incremental innovation $[50,51]$. However, although the academic circle has conducted many beneficial researches on corporate innovation, the question of "how does the innovation interaction mechanism among enterprises work?" still remains to be clear. Inspired by the dynamic competition theory, which divides the corporate interaction into "attack action" and "responsive action" [52], this article introduces and studies the responsive innovation behavior of enterprises. The research conclusions not only further expands the research on the innovation behavior of enterprises, but also deepens the understanding of the inter-company innovation interaction mechanism.

On the other hand, the discovery of this article is also helpful to the research of agency theory. Although managerial ownership has become a widely accepted method to reduce agency costs [53], existing research and practice also show that managerial ownership contributes to managerial entrenchment ability [54]. This study finds that the increasing number of shares held by the parent company and the managers have opposite effects. The above conclusion shows that the difference in governance logic between shareholders and managers is still obvious, and this logic difference does not disappear due to the grant of more residual claims, and may even be enlarged.

In addition, the findings of this article complement the research on internal and external governance synergy, and further elaborate the synergy mechanism of internal and external governance factors 
on corporate innovation. Further research of the article finds that there is an 'inhibitor' effect in the external institutional environment, which not only weakens the negative impact of parent company shareholding on subsidiary responsive innovation, but also weakens the positive impact of managerial ownership on subsidiary responsive innovation.

\subsection{Managerial Implications}

The research results of the article also generate policy implications: First, listed companies should reasonably evaluate their own innovation competitiveness and the current innovation competition situation in the industry, carefully participating in innovation competition interaction. In the process of participating in innovation interaction, listed companies should further promote the construction of trust mechanism among shareholders and the protection mechanism for the interests of small and medium-sized shareholders. On the basis of fully protecting the rights and interests of small and medium-sized shareholders, the listed companies should improve the willingness of small and medium-sized shareholders to share resources, so that small and medium-sized shareholders can fully share risks and benefits. Secondly, the board of directors of listed companies should appropriately revise the evaluation mechanism for managers, improving the transparency of relevant behaviors of managers in the decision-making process, decreasing the responsive innovation projects promoted by managers due to managerial entrenchment motivation, curbing the waste of resources caused by entrenchment actions.

\subsection{Suggestions for Future Research}

We believe that future research can focus on the following aspects: (1) The interactive effect of major shareholder ownership and managerial ownership on responsive innovation of listed companies. The number of shares held by major shareholders not only changes the attitude of major shareholders towards innovation, but also changes the efficiency that major shareholders supervise the company [5]. Stricter supervision may produce an impact on the relationship between managerial ownership and responsive innovation decision-making in enterprises, which is worth focusing on in future research. (2) The results of innovation interaction among enterprises. This paper mainly focuses on the factors leading to innovation interaction among enterprises, and discusses the occurrence rules of responsive innovation among enterprises. However, the original intention of enterprises to participate in innovation activities is to improve market position. The result of innovation interaction is also one of the concerns of enterprises. Therefore, from our perspective, researchers can use financial indicators, market share, and other data to measure the market position of enterprises in the future and study the influence of innovation interaction intensity on the market position of enterprises.

Author Contributions: Conceptualization, P.X. and G.B.; Data curation, P.X.; Formal analysis, P.X. and H.Z.; Funding acquisition, P.X.; Investigation, P.X. and G.B.; Methodology, H.Z.; Project administration, P.X.; Supervision, G.B.; Validation, P.X.; Visualization, P.X. and H.Z.; Writing—original draft, H.Z.; Writing—review and editing, P.X. and G.B.

Funding: The authors gratefully acknowledge the support from National Natural Science Foundation of China (grant no. 71972117), National Natural Science Foundation of China (grant no. 71602099), Natural Science Foundation of Shandong Province (grant no. ZR2018QG003), and Natural Science Foundation of Shandong Province (grant no. ZR2016GQ04).

Conflicts of Interest: The authors declare no conflict of interest.

\section{References}

1. Griliches, Z. Productivity, R\&D, and Basic Research at the Firm Level in the 1970's. Am. Econ. Rev. 1986, 76, 141-154.

2. Cornaggia, J.; Mao, Y.; Tian, X.; Wolfe, B. Does banking competition affect innovation? J. Financ. Econ. 2015, 115, 189-209. 
3. Yu, M.C.; Mai, Q.; Tsai, S.B.; Dai, Y. An empirical study on the organizational trust, employee-organization relationship and innovative behavior from the integrated perspective of social exchange and organizational sustainability. Sustainability 2018, 10, 864.

4. Jensen, M.C.; Meckling, W.H. Theory of the firm: Managerial behavior, agency costs and ownership structure. J. Financ. Econ. 1976, 3, 305-360.

5. Jia, N.; Huang, K.G.; Man Zhang, C. Public governance, corporate governance, and firm innovation: An examination of state-owned enterprises. Acad. Manag. J. 2019, 62, 220-247.

6. Minetti, R.; Murro, P.; Paiella, M. Ownership structure, governance, and innovation. Eur. Econ. Rev. 2015, 80, 165-193.

7. Chen, M.J.; Miller, D. Reconceptualizing competitive dynamics: A multidimensional framework. Strateg. Manag. J. 2015, 36, 758-775.

8. Fama, E.F.; Jensen, M.C. Separation of ownership and control. J. Law Econ. 1983, 26, 301-325.

9. Ortega-Argiles, R.; Moreno, R.; Caralt, J.S. Ownership structure and innovation: Is there a real link? Ann. Reg. Sci. 2005, 39, 637-662.

10. Lin, C.; Lin, P.; Song, F.M.; Li, C. Managerial incentives, CEO characteristics and corporate innovation in China's private sector. J. Comp. Econ. 2011, 39, 176-190.

11. Lskavyan, V.; Spatareanu, M. Shareholder protection, ownership concentration and FDI. J. Econ. Bus. 2011, 63, 69-85.

12. Hsieh, T.J.; Yeh, R.S.; Chen, Y.J. Business group characteristics and affiliated firm innovation: The case of Taiwan. Ind. Market. Manag. 2010, 39, 560-570.

13. Ossorio, M. Does R\&D investment affect export intensity? The moderating effect of ownership. Int. J. Manag. Financ. Account. 2018, 10, 65-83.

14. Scherer, F.M. Firm size, market structure, opportunity, and the output of patented inventions. Am. Econ. Rev. 1965, 55, 1097-1125.

15. Meng, J.; Weng, X. Can prospect theory explain the disposition effect? A new perspective on reference points. Manag. Sci. 2017, 64, 3331-3351.

16. Kahneman, D.; Tversky, A. Prospect Theory: An Analysis of Decision under Risk. Econometrica $1979,47,263-292$.

17. Wei, K.C.J.; Zhang, Y. Ownership structure, cash flow, and capital investment: Evidence from East Asian economies before the financial crisis. J. Corp. Financ. 2008, 14, 118-132.

18. Paligorova, T.; Xu, Z. Complex ownership and capital structure. J. Corp. Financ. 2012, 18, 701-716.

19. Widyaningsih, I.U.; Gunardi, A.; Rossi, M. Expropriation by the controlling shareholders on firm value in the context of Indonesia: Corporate governance as moderating variable. Int. J. Manag. Financ. Account. 2017, 9, 322-337.

20. Masulis, R.W.; Pham, P.K.; Zein, J. Family business groups around the world: Financing advantages, control motivations, and organizational choices. Rev. Financ. Stud. 2011, 24, 3556-3600.

21. Fan, J.P.H.; Wong, T.J.; Zhang, T. Institutions and organizational structure: The case of state-owned corporate pyramids. J. Law Econ. Organ. 2013, 29, 1217-1252.

22. Keil, T.; Maula, M.; Syrigos, E. CEO entrepreneurial orientation, entrenchment, and firm value creation. Entrep. Theory Pract. 2017, 41, 475-504.

23. Rashid, A. Managerial ownership and agency cost: Evidence from Bangladesh. J. Bus. Ethics 2016, 137, 609-621.

24. Chen, L.Y.; Chen, Y.F.; Yang, S.Y. Managerial incentives and R\&D investments: The moderating effect of the directors' and officers' liability insurance. N. Am. J. Econ. Financ. 2017, 39, 210-222.

25. Levy, M.; Szafarz, A. Cross-Ownership: A Device for Management Entrenchment? Rev. Financ. 2016, 21, 1675-1699.

26. Walsh, J.P.; Seward, J.K. On the efficiency of internal and external corporate control mechanisms. Acad. Manag. Rev. 1990, 15, 421-458.

27. Burks, S.V.; Carpenter, J.P.; Goette, L.; Rustichinil, A. Overconfidence and social signal ling. Rev. Econ. Stud. 2013, 80, 949-983.

28. Nofsinger, J.R. Social mood and financial economics. J. Behav. Financ. 2005, 6, 144-160.

29. Zona, F. Board leadership structure and diversity over CEO time in office: A test of the evolutionary perspective on Italian firms. Eur. Manag. J. 2013, 32, 672-681. 
30. Rossi, M.; Nerino, M.; Capasso, A. Corporate governance and financial performance of Italian listed firms. The results of an empirical research. Corp. Ownersh. Control 2015, 12, 628-643.

31. Peng, M.W.; Li, Y.; Xie, E. CEO duality, organizational slack, and firm performance in China. Asia Pac. J. Manag. 2010, 27, 611-624.

32. Weisbach, M.S. Outside directors and CEO turnover. J. Financ. Econ. 1988, 20, 431-460.

33. Chen, M.J.; MacMillan, I.C. Nonresponse and delayed response to competitive moves: The roles of competitor dependence and action irreversibility. Acad. Manag. J. 1992, 35, 539-570.

34. Goranova, M.; Alessandri, T.M.; Brandes, P.; Dharwadkar, R. Managerial ownership and corporate diversification: A longitudinal view. Strateg. Manag. J. 2007, 28, 211-225.

35. Ofek, E.; Yermack, D. Taking stock: Equity-based compensation and the evolution of managerial ownership. J. Financ. 2000, 55, 1367-1384.

36. La Porta, R.; Lopez-de-Silanes, F.; Shleifer, A. Corporate ownership around the world. J. Financ. 1999, 54, 471-517.

37. Claessens, S.; Djankov, S.; Lang, L.H.P. The separation of ownership and control in East Asian corporations. J. Financ. Econ. 2000, 58, 81-112.

38. Ruigrok, W.; Peck, S.I.; Keller, H. Board characteristics and involvement in strategic decision making: Evidence from Swiss companies. J. Manag. Stud. 2006, 43, 1201-1226.

39. Choi, S.B.; Lee, S.H.; Williams, C. Ownership and firm innovation in a transition economy: Evidence from China. Res. Policy 2011, 40, 441-452.

40. Zhou, K.Z.; Gao, G.Y.; Zhao, H. State ownership and firm innovation in China: An integrated view of institutional and efficiency logics. Adm. Sci. Q. 2017, 62, 375-404.

41. Bartoloni, E. Capital structure and innovation: Causality and determinants. Empirica 2013, 40, 111-151.

42. Li, M.; Simerly, R.L. Environmental dynamism, capital structure and innovation: An empirical test. Int. J. Organ. Anal. 2002, 10, 156-171.

43. Shefer, D.; Frenkel, A. R\&D, firm size and innovation: An empirical analysis. Technovation 2005, 25, 25-32.

44. Hall, B.H.; Ziedonis, R.H. The patent paradox revisited: An empirical study of patenting in the US semiconductor industry, 1979-1995. RAND J. Econ. 2001, 1, 101-128.

45. Zahra, S.A.; Neubaum, D.O.; Huse, M. Entrepreneurship in medium-size companies: Exploring the effects of ownership and governance systems. J. Manag. 2000, 26, 947-976.

46. Balsmeier, B.; Fleming, L.; Manso, G. Independent boards and innovation. J. Financ. Econ. 2017, 123, 536-557.

47. Ouyang, C.; Wang, X.; Xiong, J. Do Controlling Shareholders Who Pledged Their Shares Affect Sustainable Development? An Investigation Based on the Perspective of Corporate Innovation. Sustainability 2019, 11, 2754.

48. Chen, H.L.; Hsu, W.T. Family ownership, board independence, and R\&D investment. Fam. Bus. Rev. 2009, 22, 347-362.

49. Carney, M.; Shapiro, D.; Tang, Y. Business group performance in China: Ownership and temporal considerations. Manag. Organ. Rev. 2009, 5, 167-193.

50. Forés, B.; Camisón, C. Does incremental and radical innovation performance depend on different types of knowledge accumulation capabilities and organizational size? J. Bus. Res. 2016, 69, 831-848.

51. Zhou, K.Z.; Li, C.B. How knowledge affects radical innovation: Knowledge base, market knowledge acquisition, and internal knowledge sharing. Strateg. Manag. J. 2012, 33, 1090-1102.

52. Alexander, L.; Van Knippenberg, D. Teams in pursuit of radical innovation: A goal orientation perspective. Acad. Manag. Rev. 2014, 39, 423-438.

53. Mustapha, M.; Che Ahmad, A. Agency theory and managerial ownership: Evidence from Malaysia. Manag. Audit. J. 2011, 26, 419-436.

54. Lasfer, M.A. The interrelationship between managerial ownership and board structure. J. Bus. Financ. Account. 2006, 33, 1006-1033.

(C) 2019 by the authors. Licensee MDPI, Basel, Switzerland. This article is an open access article distributed under the terms and conditions of the Creative Commons Attribution (CC BY) license (http://creativecommons.org/licenses/by/4.0/). 